\title{
NIMBY TAXES MATTER: STATE TAXES AND INTERSTATE HAZARDOUS WASTE SHIPMENTS
}

\author{
Arik Levinson
}

Working Paper 6314 


\title{
NIMBY TAXES MATTER: STATE TAXES AND INTERSTATE HAZARDOUS WASTE SHIPMENTS
}

\author{
Arik Levinson
}

Working Paper 6314

http://www.nber.org/papers/w6314

\author{
NATIONAL BUREAU OF ECONOMIC RESEARCH \\ 1050 Massachusetts Avenue \\ Cambridge, MA 02138 \\ December 1997
}

This paper has benefitted from funding provided by the National Science Foundation, research assistance by Victor Davis, and helpful comments from numerous reviewers including Jim Andreoni, Don Fullerton, Vernon Henderson, John Karl Scholz, and Jim Walker. Any opinions expressed are those of the author and not those of the National Bureau of Economic Research.

(C) 1997 by Arik Levinson. All rights reserved. Short sections of text, not to exceed two paragraphs, may be quoted without explicit permission provided that full credit, including (C) notice, is given to the source. 
NIMBY Taxes Matter: State Taxes and Interstate

Hazardous Waste Shipments

Arik Levinson

NBER Working Paper No. 6314

December 1997

JEL Nos. H73, H23

\section{ABSTRACT}

This paper examines the extent to which state taxes have inhibited interstate transport of hazardous waste for disposal in the United States. It uses panel data from the Toxics Release Inventory (TRI) and the Resource Conservation and Recovery Act (RCRA) on interstate shipments of waste, and analyzes them in conjunction with a set of state characteristics, including hazardous waste disposal taxes and disposal capacity. It employs four approaches to deal with the potential endogeneity of taxes and unobserved heterogeneity among states: a "natural experiment" based on the retaliatory nature of some state tax laws, a fixed-effects model, a two-stage least squares estimator, and a reinterpretation of the coefficient on the distance among states. The paper concludes that hazardous waste taxes are a statistically and economically significant deterrent to interstate waste transport, that taxes are being imposed by large-capacity and large-import states, and that therefore these taxes have had a decentralizing effect on the national pattern of hazardous waste transport and disposal.

\section{Arik Levinson}

Department of Economics

University of Wisconsin, Madison

1180 Observatory Drive

Madison, WI 53706

and NBER

amlevins@facstaff.wisc.edu 


\section{Introduction.}

Hazardous waste is among the fastest growing components of environmental compliance costs in the U.S. (CEQ, 1995), and consistently tops public opinion polls as the most important environmental problem (Roper, 1991). In recent years many states have substantially increased the rate at which they tax disposal of hazardous waste, and a few have imposed higher taxes on waste imported from other states. These taxes exemplify the "not-in-my-backyard" (NIMBY) sentiment that characterizes many aspects of local environmental policy, and this paper measures the extent to which these NIMBY taxes have altered interstate shipments of hazardous waste and changed the national pattern of hazardous waste transport and disposal.

The topic deserves heightened attention for several reasons. First, the deterrent effect of disposal taxes on interstate shipments is not obvious from aggregate or even cross-section data: States with relatively high tax rates import relatively more waste. As shown in what follows, however, endogeneity of tax rates and unobserved heterogeneity typical of cross-state policy studies complicates the empirical modeling of taxes and waste flows. This paper employs a panel of tax and shipment data and four separate approaches to isolate the effect of an exogenous change in taxes on waste flows, holding state characteristics constant.

Second, even if the direction of the effect of disposal taxes on waste shipments were obvious, its magnitude is not. Anecdotal evidence has led analysts to claim that hazardous waste disposal taxes raise significant revenues for states, deter imports of waste, or both. ${ }^{1}$ In theory

'Alabama's $\$ 72$ per ton import fee was credited with halving the amount of hazardous waste being received by the state's largest facility, while contributing $\$ 30$ million to the state's general revenues (Walters, 1991). 
hazardous waste generators could respond in varying degrees to these taxes by reducing the amount of waste generated in the first place (pollution prevention), by increasing the amount of waste disposal on-site or into other environmental media (air or water pollution), or by merely shifting disposal among jurisdictions to reduce tax liability. This paper measures the magnitude of these options.

Third, the extent to which these local taxes affect national patterns of hazardous waste transport has significant implications for federal environmental policy. For 25 years economists and policymakers have debated the optimal level of federal responsibility for environmental regulation (Stein, 1971; Peltzman and Tideman, 1972), and since 1980 regulatory authority for many environmental programs has been devolving from the federal government to state and local governments. It is impossible to predict a priori the effect of this change on environmental stringency because most polluters confer some benefits on local jurisdictions in the form of tax revenue and employment. In some situations states may compete to attract polluting firms by lowering environmental standards in a "race to the bottom." In others, states may compete to deter polluting activity by hiking up standards, a "race to the top" or NIMBY outcome. ${ }^{2}$ This paper examines hazardous waste disposal as an example of an economic activity that, by imposing large costs and small benefits on local jurisdictions, would be expected to result in the latter form of interjurisdictional competition--a race to the top in environmental regulatory stringency.

${ }^{2}$ Both situations have been formally modeled (Oates and Schwab, 1988; Markusen et al., 1995). The outcome depends on the parameters of the models, including the tastes of citizens and the pollution-intensity of the relevant industry. 
Finally, this research brings evidence to bear on the legal debate over the constitutionality of state laws that discriminate among wastes according to their state of origin. In 1992 in Chemical Waste v. Hunt the Supreme Court declared unconstitutional an Alabama fee charging an extra $\$ 72$ per ton for disposal of waste generated outside Alabama, finding that it violated the interstate commerce clause of the United States Constitution. Despite the Court's obvious distaste for discriminatory tariffs on out-of-state waste, such policies continue to be enacted. Some states have carefully written regulations to avoid constitutional challenge, while others may simply be taking advantage of lengthy legal processes to restrict interstate commerce temporarily. As Oregon's chief environmental official phrased it, "If any state wants to be creative in banning stuff from coming in, they can find ways to do it. It may not hold up in court, but it takes three years for it to get knocked down" (Walters, 1991). Furthermore, several federal bills have proposed authorizing states to ban or tax out-of-state waste. ${ }^{3}$ If states are permitted to erect tariff barriers to hazardous waste imports, the result could be a general decentralization of hazardous waste disposal in a way that reduces economic efficiency and environmental safety.

The next section of this paper presents a conceptual framework for considering the issues involved in interstate hazardous waste transportation and taxation. Section III describes the data to be used, and section IV presents econometric estimates of the effect of hazardous waste disposal taxes on interstate shipments.

${ }^{3}$ The latest example is the Municipal Solid Waste Flow Control Act, proposed during the 104th Congress, which would have explicitly authorized states to limit interstate transport of solid waste. 


\section{Conceptual framework: A partial equilibrium theory of hazardous waste taxation.}

Models of pollution as a factor of production are well developed (Cropper and Oates, 1992), and models of interjurisdictional competition for pollution-intensive industries are also well established (Oates and Schwab, 1988; Markusen, et al., 1995). However, the literature does not specifically address hazardous waste, which has the unique feature that the negative externalities caused by the waste can be deliberately separated from the physical location of the industry generating the waste. Unlike water or air pollution, the damage from which either occurs locally or is transported by natural mechanisms, much of the hazardous waste generated in the United States is intentionally transported away from the site of generation to some chosen disposal site.

Suppose that there exist $M$ jurisdictions indexed $j=1 \ldots M$. Each jurisdiction begins with some fixed level of industrial activity. Each citizen in jurisdiction $j$ derives utility from $y_{j}$, a composite consumption good, and disutility from $e_{j}$, a public bad associated with the amount of hazardous waste disposed of nearby: $U_{j}=U_{j}\left(y_{j} ; e_{j}\right)$. The public bad, $e_{j}$, is taken as exogenous by individuals. It may depend on many factors, including the jurisdiction's amount of hazardous waste disposal, $W_{j}$, and its area, $a_{j}$. The area of the jurisdiction is included because many studies have shown that people's aversion to hazardous waste facilities declines with distance (Mitchell and Carson, 1986; Smith and Desvousges, 1986). The larger the area, the more distant such facilities are likely to be from population centers. Because states often distinguish locally generated waste from imported waste, hazardous waste disposal is divided into two components, the amount disposed of by domestic (local) generators, $W_{j}^{D}$, and the amount disposed of by 
foreign (out-of-state) generators, $W_{j}^{F}$. The public bad can then be written $e_{j}=e\left(W_{j}{ }^{D}+W_{j}^{F}, a_{j}\right){ }^{4}$ and each citizen's utility is

$$
U_{j}=U_{j}\left(y_{j} ; e\left(W_{j}^{D}+W_{j}^{F}, a_{j}\right)\right) .
$$

Let individuals have exogenous incomes, $I_{j}$, that vary by jurisdiction. In addition, they receive their share of the surplus from local firms generating hazardous waste, and their share of revenue from taxing the disposal of hazardous waste. Individuals' budget constraints are thus

$$
y_{j}=I_{j}+\frac{1}{n_{j}} S_{j}+\frac{1}{n_{j}}\left(\tau_{j}^{D} W_{j}^{D}+\tau_{j}^{F} W_{j}^{F}\right),
$$

where $n_{j}$ is the population of jurisdiction $j, S_{j}$ is the producer and consumer surplus from local production, $\tau_{j}^{D}$ is the tax rate jurisdiction $j$ imposes on disposal of hazardous waste by domestic firms, and $\tau_{j}^{F}$ is the tax rate jurisdiction $j$ imposes on disposal of hazardous waste by foreign firms.

Jurisdictions may benefit from local production in many ways: locally accrued profits, increased marginal product of labor, increased land rents, etc. Assume that this surplus, $S_{j}$, is a positive function of hazardous waste generated, and a negative function of the cost of disposing of that hazardous waste. Firms use competitively supplied inputs to produce $y_{j}$, a composite consumption good, and in the process generate hazardous waste, $g_{\jmath}$. Normalizing the price of output to one, local surplus is

$$
S_{j}=\mathrm{f}^{\mathrm{j}}\left(g_{j}\right)-q g_{j}
$$

${ }^{4}$ Although $W_{j}^{D}$ and $W_{j}^{F}$ are perfect substitutes in production of $e_{j}$, states in this model will want to tax them differently in order to export some of the incidence of the tax. 
where $\mathrm{f}(\cdot)$ is a production function and $q_{j}$ is the marginal cost of disposing of hazardous waste, $g_{j}$. Prices and quantities of other inputs and taxes of other jurisdictions are considered exogenous, and local producers are assumed to maximize this local surplus, $S_{j}$.

In the process of maximizing surplus, firms minimize costs by disposing of waste in the single least expensive manner, which may mean shipping it to another jurisdiction. The leastexpensive disposal option for a firm in jurisdiction $j$ has marginal cost

$$
q_{j}=\min \left(\tau_{j}^{D},\left\{\tau_{k}^{F}+c d_{j k}: j \neq k\right\}\right)
$$

where $c$ is the cost per mile of shipping waste and $d_{j k}$ is the distance between jurisdictions $j$ and $k^{5}$ Equation (4) thus provides the minimum disposal cost, accounting for disposal taxes and shipping costs.

\begin{tabular}{ll}
\hline Variable & Definition \\
\hline$\tau_{j}^{D}$ & tax rate on disposal of waste generated by domestic (local) firms. \\
$\tau_{j}^{F}$ & tax rate on disposal of waste generated by foreign (out-of-state) firms. \\
$q_{j}$ & minimum hazardous waste disposal cost for firms in jurisdiction $\mathrm{j}$. \\
$I_{j}$ & exogenous incomes in jurisdiction $j$. \\
$a_{j}$ & area of jurisdiction $j$. \\
$n_{j}$ & population of jurisdiction $j$. \\
$W_{j}^{D}$ & hazardous waste deposited by domestic (local) firms in jurisdiction $j$. \\
$W_{j}^{F}$ & hazardous waste deposited by foreign (out-of-state) firms in jurisdiction $j$. \\
$S_{j}$ & consumer and producer surplus from local production in jurisdiction $j$. \\
$\mathrm{g}_{\mathrm{j}}$ & hazardous waste generation in jurisdiction $\mathrm{j}$. \\
$y_{j}$ & a composite good. \\
$c$ & transport cost per ton-mile. \\
$e_{j}$ & public bad caused by hazardous waste in jurisdiction $j$. \\
$d_{j k}$ & distance in miles between jurisdictions $j$ and $k$. \\
\hline
\end{tabular}

${ }^{5}$ This ignores the pre-tax price of hazardous waste disposal. Empirically, these prices are unobservable as they are contained in private contracts between transporters and waste facilities, many of which are owned by the same corporations (Peretz and Solomon, 1995). 
Assume that local regulators maximize their constituents' utility, (1), with respect to $\tau_{j}^{D}$ and $\tau_{j}^{F}$, and subject to (2), (3), and (4), taking into account firms' maximization of (3). The first order condition with respect to the tax rate on hazardous waste disposal by foreign generators is

$$
W_{j}^{F}+\tau_{j}^{F}\left(\frac{\partial W_{j}^{F}}{\partial \tau_{j}^{F}}\right)=-n_{j}\left(\frac{\partial U_{j} \partial e_{j}}{\partial U_{j} \partial y_{j}}\right)\left(\frac{\partial e_{j}}{\partial W_{j}^{F}}\right)\left(\frac{\partial W_{j}^{F}}{\partial \tau_{j}^{F}}\right) .
$$

Regulators should increase the tax rate on imported waste until the marginal revenue (left-hand side) is equal to the marginal social disutility from the public bad (right-hand side). Note that both sides of equation (5) are negative. Raising the disposal tax on foreign generators makes the environment cleaner and generates more revenue. If there were no externality, and this were merely an exercise in tax exporting, then jurisdictions would raise the tax until the marginal revenue was equal to zero, or $W_{j}^{F}+\tau_{j}^{F}\left(\partial W_{j}^{F} / \partial \tau_{j}^{F}\right)=0$. Because of the added benefit of a cleaner environment, the tax is higher than this revenue-maximizing point.

If local disposal is least costly, then local generators will dispose of all waste locally, $g_{j}=\mathrm{W}_{j}^{D}, q_{j}=\tau_{j}^{D}$ and the first order condition with respect to the tax rate on hazardous waste disposal by domestic generators is ${ }^{6}$

$$
\frac{\partial \mathrm{f}^{\mathrm{j}}}{\partial g_{j}} \frac{\partial g_{j}}{\partial \tau_{j}^{D}}=-n_{j}\left(\frac{\partial U_{j} / \partial e_{j}}{\partial U_{j} / \partial y_{j}}\right)\left(\frac{\partial e_{j}}{\partial W_{j}^{D}}\right)\left(\frac{\partial W_{j}^{D}}{\partial \tau_{j}^{D}}\right) .
$$

Equation (6) differs from equation (5) in that superscript $D$ s replace superscript $F \mathrm{~s}$, and the lefthand side consists only of the effect of domestic disposal taxes on domestic generation.

${ }^{6}$ Equation (6) has been simplified by noting that from a social perspective the firm's marginal domestic tax payments and the state's marginal domestic tax revenues cancel: $g+\tau^{D}\left(\partial g / \partial \tau^{D}\right)=W^{D}+\tau^{D}\left(\partial W^{D} / \partial \tau^{D}\right)$. 
Equation (6) indicates that marginal private cost of the local tax (reduced output) should be set equal to the marginal social benefit of the tax (reduced local disposal).

To compare the domestic and import tax rates $\left(\tau_{j}^{D}\right.$ and $\left.\tau_{j}^{F}\right)$, note that $\partial e_{j} / \partial W_{j}^{D}=\partial e_{j} / \partial W_{j}^{F}$, and that therefore the right-hand sides of (5) and (6) differ only in the last term, $\partial W_{j}^{D} / \partial \tau_{j}^{D}$. Furthermore, one can use the fact that surplus-maximizing firms will set $\partial \mathrm{f} / \partial g_{j}=\tau_{j}^{D}$, along with the social equalities in footnote 6, to rewrite equations (5) and (6) (with jurisdiction subscripts suppressed)

$$
\begin{gathered}
\tau^{F}=K\left(1-\frac{1}{\eta^{F}}\right)^{-1} \\
\tau^{D}=K\left(1-\frac{1-g / W^{D}}{\eta^{D}}\right)^{-1}
\end{gathered}
$$

where $K=-n\left(\frac{\partial U / \partial e}{\partial U / \partial y}\right)\left(\frac{\partial e}{\partial W}\right)$ is the social marginal cost of waste disposal, and $\eta^{F}=-\left(\frac{\partial W^{F}}{\partial \tau^{F}}\right)\left(\frac{\tau^{F}}{W^{F}}\right)$ and $\eta^{D}=-\left(\frac{\partial W^{D}}{\partial \tau^{D}}\right)\left(\frac{\tau^{D}}{W^{D}}\right)$ are the tax elasticities of foreign and domestic waste disposal, respectively. Equation (5a) is simply the optimal price for a single-price monopolist whose marginal cost is $K$. As a single-price monopolist, the jurisdiction will always want to operate on the elastic portion of the demand curve $\left(\eta^{F}>1\right)$. Therefore the jurisdiction will want to set $\tau^{F}>K$. In other words, the optimal tax on imported waste will be higher than the social marginal cost of waste disposal due to the fact that the jurisdiction exports some of the incidence of that tax to residents of other jurisdictions.

Equations (6) and (6a) were derived assuming that states minimize costs in such a way that they will either export all waste or none. This means that either $W^{D}=0$ or $W^{D}=g$. If $W^{D}=0$, the state disposes of none of its own waste, then $\tau^{D}$ is irrelevant. If $W^{D}=g$, the state disposes of 
all of its own waste, then equation (6a) indicates that $\tau^{D}=K$, which is the social marginal cost of waste disposal. In other words, all interjurisdictional issues are absent and the tax is equal to the first-best Pigouvian tax, $K$. Combined with the result of the previous paragraph, that $\tau^{F}>K$, this leads to the intuitive result that $\tau^{F}>\tau^{D}$ : States will want to tax imported waste at higher rates than domestic waste.

Although equation (6a) was derived assuming that states minimize costs in such a way that they will either export all waste or none, alternative scenarios can be examined loosely. If the state exports some fraction of its waste, then $g>W^{D}$, but $g$ can never be less than $W^{D}$, so $g / W^{D} \geq 1$. Furthermore, note that $\partial \tau^{D} / \partial\left(g / W^{D}\right)<0$, indicating that as $g / W^{D}$ rises above 1 (the state exports some of its locally generated waste), the optimal domestic tax declines below $K$, all else equal, thus widening the gap between the optimal tax on domestic and imported waste. So if $\eta^{F}=\eta^{D}$ jurisdictions will always want to tax imported waste at higher rates than locally generated waste $\left(\tau^{F}>\tau^{D}\right)$, just as in the simple case where $g=W^{D}$. However, if $\eta^{F}$ is sufficiently larger (more elastic) than $\eta^{D}$, then the jurisdiction will desire to tax imports at a lower rate than local waste. In particular, $\tau^{F}>\tau^{D}$ as long as $\eta^{D}>\eta^{F}\left(1-g / W^{D}\right)$.

In general, both $\tau^{F}$ and $\tau^{D}$ will be inefficient from a social perspective: $\tau^{F}$ will be too high and $\tau^{D}$ too low $\left(\tau^{F}>K>\tau^{D}\right)$. Taxes on imported waste, $\tau^{F}$, are borne in part by firms in other jurisdictions, and that burden is not considered by local regulators (tax exporting). Taxes on locally generated waste, $\tau^{D}$, may shift local hazardous waste to other jurisdictions where it imposes external costs not taken into account by local regulators (pollution exporting). The rest of this paper examines some of the implications of this model using state-level tax and hazardous waste data, and explores the effect of these taxes on interstate shipments of hazardous waste. 


\section{Data.}

This project uses an annual panel of hazardous waste disposal taxes for the 48 continental states for recent years, compiled from Commerce Clearing House publications and from telephone conversations with state tax officials. The task was complicated by the fact that many states impose "retaliatory" taxes. South Carolina, for example, currently charges either $\$ 34$ per ton or the per-ton fee charged on out-of-state waste by the state from which the waste originated, whichever is higher. So each state has the potential for 48 separate hazardous waste tax rates, one for each state of origination. ${ }^{7}$ Thus the resulting panel of tax rates contains 2304 (48 squared) observations per year. One result of the retaliatory taxes is that each change in any state's tax law is reflected in other states' effective tax rates, and the variation over time in actual disposal fees is greater than would be expected from the frequency of statutory fee changes.

In constructing the tax panel, I made several assumptions that need to be noted. First, because the waste transport data are annual and many state laws change mid-year, I approximated annual tax rates by averaging the number of months that each rate was in effect. A few states express their tax rates per gallon of waste (e.g. Maine). I convert these to per-ton rates by multiplying by the number of gallons in a ton of water (239.7). Several states impose taxes on the gross revenue earned by hazardous waste disposal facilities. Because these taxes are small relative to disposal taxes, they are ignored here. ${ }^{8}$ I also ignore taxes that may be imposed by

\footnotetext{
${ }^{7}$ In practice, of course, most of these are identical. South Carolina's tax is $\$ 34$ for imports from all states but those whose rates exceed $\$ 34$.

${ }^{8}$ In 1995 five states imposed taxes on the gross receipts of facilities, ranging from 2 percent in Missouri to 10 percent in Connecticut.
} 
counties or other local jurisdictions. In addition, states have a wide variety of license fees that affect firms involved in hazardous waste generation, transport or disposal. Because most are small, relative to the disposal taxes, and because most are best characterized as fixed costs (though some vary step-wise with the amount of activity), I ignore these various licensing fees. Several states (LA, MA, PA) have imposed large per-ton transport fees. I treat these as import taxes because they do not affect the choice by local firms who pay the fee no matter where they send the waste. Similarly, many states charge generator fees and apply those fees to out-of-state waste. I consider these import taxes for the same reason: They affect the decision of waste importers only.

Data on interstate shipments of waste come from the Toxics Release Inventory (TRI). The TRI is collected by the EPA as mandated by the 1986 Emergency Planning and Community Right-to-Know Act. It is an annual census of manufacturing establishments with 10 or more full-time employees that manufacture or process more than 25 thousand pounds of any toxic chemical. Each facility reports its location, the quantity of each chemical transferred off-site, the location to which it was transferred, and the purpose of the shipment (land disposal, recycling, incineration, etc.). Though the TRI data are available from 1987 to 1993 , the first two years are censored at high levels ( 75 thousand and 50 thousand pounds), and are generally considered less reliable than later data. Consequently, the analyses that follow examine the sum of TRI waste shipped off-site for disposal purposes from 1989 to 1993.

Another potential source of data on interstate waste shipments is that collected by the states under the auspices of the 1984 amendments to the Resource Conservation and Recovery Act (RCRA). RCRA defines hazardous waste as toxic, corrosive, reactive, or explosive. 
Although most of the hazardous waste disposal taxes studied here are based on RCRA definitions, the RCRA data are imperfect for this project for several reasons. First, they are only available for three years: 1991, 1993, and 1995. Second, each handler of waste files separate paperwork. In other words, if waste is shipped from a generator in one state to a treatment facility in a second state, and then on to a disposal facility in a third state, both shipments appear in the RCRA data. Consequently, it is impossible to identify the origin and destination of waste shipments without double-counting some shipments. Third, large contiguous facilities often have more than one EPA identification number. As a result, some waste that appears to be generated by one facility and disposed of by another, and which therefore appears to involve an off-site shipment, may actually be an on-site disposal by one facility with two EPA identification numbers. Nevertheless, as a robustness check to the TRI results, I also report results using the RCRA data.

While the TRI is limited to manufacturing establishments, the manufacturing sector made up 58 percent of generators and accounted for 98 percent of the RCRA waste generated in 1989 (EPA 1993). ${ }^{9}$ The TRI is also limited to toxic wastes, omitting those that are exclusively corrosive, reactive or explosive; however, much of the RCRA waste fits this classification. ${ }^{10}$ In sum, the RCRA data measure the volume of waste including waste water or soil, which is the measure on which local taxes are based. The TRI measures toxic chemicals from manufacturers;

\footnotetext{
${ }^{9}$ The rest of the RCRA waste is generated by agriculture, services, mining, and the government.

${ }^{10}$ Although the exact proportion of RCRA waste that would be characterized as toxic is difficult to calculate from published data, the least it could be is 37 percent and the most 79 percent (EPA, 1995).
} 
however, manufacturers contribute the bulk of the RCRA volume, and most of the RCRA waste is classified as "toxic."

The rest of the data used below describe characteristics of the 48 continental states. Population, median household income, and area come from the U.S. Census Bureau. The percent of gross state product derived from the manufacturing sector comes from the U.S. Bureau of Economic Analysis, and the percent voting Republican in the 1988 presidential election comes from the Statistical Abstract of the U.S. State-level data on hazardous waste disposal capacity come from Capacity Assurance Plans filed by states complying with the federal Superfund law (EPA, 1994).

\section{An empirical analysis of the effects of hazardous waste disposal taxes on interstate waste shipments.}

At first glance, recent years seem to be characterized by a race to the top in hazardous waste disposal taxes, as average disposal taxes doubled and many states imposed discriminatory tariffs on imported waste. As a result of these tax increases one would expect an increasing fraction of hazardous waste to be disposed of in the state in which it was generated. If larger, more concentrated disposal facilities are safer and more efficient, then the decentralizing effect of these taxes may have adverse effects on the environment and human health and safety. However, the aggregate data do not reveal any such response.

Table 1 describes some characteristics of states with and without hazardous waste disposal taxes as of 1991. Those states assessing taxes have similar median household incomes, larger populations and land areas, and smaller population densities and percentages over age 65 
and with college degrees. States with taxes also generate more hazardous waste, have similar hazardous waste capacity, and import from other states vastly larger quantities of waste as measured by either the TRI or RCRA data. This last observation, that states with taxes import more waste, provides strong initial evidence that the tax rates are endogenous.

Table 2 contains aggregate figures from the tax and shipment data described in the previous section. The first three columns present the number of states with taxes and their average tax rates per ton. Between 1987 and 1995 the number of states taxing off-site waste disposal increased from 21 to 33 , and the average tax increased by more than 75 percent in real terms before falling after the 1992 Supreme Court verdict. Note, however, that there is much more variation over time than is suggested by the changes in the overall averages. Between 1991 and 1992, for example, 497 (22 percent) of the 2304 state-to-state taxes increased while 103 (4 percent) declined. In addition, in any given year as many as 16 states imposed higher taxes on imported waste than on locally generated waste. Despite these changing taxes, it is difficult to see their effect in the aggregate data in Table 2. The fraction of TRI off-site disposal shipments that crossed state borders vacillated between 21 and 29 percent, with no clear trend. So if the rise in state off-site disposal taxes has deterred interstate hazardous waste shipments, its effect is not apparent in aggregate. ${ }^{11}$

"Part of the problem reflects inconsistencies in the data from year to year. The list of chemicals reported to the TRI has changed slightly over time, and the Pollution Prevention Act of 1990 added recycling, energy recovery, and treatment to the list of reportable activities in the TRI. The drop in disposal shipments in 1991 in column (4) is probably due to erroneous classification of off-site disposal shipments prior to 1991. These misclassifications could affect the analyses below, but the results using the TRI are robust to the exclusion of the 1989-90 data. 
It is possible to see the aggregate effect of these taxes, but only by looking at changes in tax rates over time. For example, between 1991 and 1993, 11 states increased their hazardous waste disposal taxes, while 37 states' tax rates remained constant or declined. The 37 states with non-increasing taxes saw a 3 percent decline in TRI imports for disposal, whereas the 11 states with increased taxes saw a 19 percent decline in TRI imports for disposal. So while all interstate TRI shipments declined by 5 percent between 1991 and 1993, the decrease was largest to states increasing their disposal taxes. While these differences provide preliminary evidence that tax increases have shifted waste away from high-tax states, both the size of the effect and its general direction are extremely sensitive to the time period examined and the grouping of states.

To place more structure on the problem, I borrow from the literature on interstate human migration (DaVanzo, 1981; Schultz, 1982). Assume that the number of tons of waste going from state $i$ to state $j$ in any given period $t, W_{i j}$, follows a conditional distribution with mean $\lambda_{i j \text { r }}$. In particular, let the conditional expectation of $W_{i j t}$ be equal to

$$
\begin{aligned}
\mathrm{E}\left[W_{i j t} \mid X_{i j t} \tau_{i j t} \tau_{i t} g_{i t}\right] & =\lambda_{i j} g_{i t} \\
& =\exp \left[X_{i j t}^{\prime} \beta+\delta \tau_{i j t}+\ln \left(g_{i t}\right)\right]
\end{aligned}
$$

where $\lambda_{i j t}$ is an exponential function of $X_{i j t}$, the characteristics of the two states, and $\tau_{i j,}$, the statepair-specific tax rate, and $g_{i t}$ is the amount of waste generated in state $i$. The migration literature then typically estimates

$$
\ln \left(\frac{W_{i j t}}{g_{i t}}\right)=X_{i j t}^{\prime} \beta+\delta \tau_{i j t}+\varepsilon_{i j t}
$$

which is equivalent to estimating

$$
\ln \left(W_{i j t}\right)=X_{i j t}^{\prime} \beta+\gamma \log \left(g_{i t}\right)+\delta \tau_{i j t}+\varepsilon_{i j t}
$$


where $\gamma$ is constrained to be equal to 1 . With human migration, such a constraint is sensible, as the dependent variable in equation (10) can be thought of as the log of the probability that any given person in state $i$ will migrate to state $j$. The human migration probability is likely to be uncorrelated with the number of people living in state $i$. For waste disposal, however, there are many reasons that the probability of transport from $i$ to $j$ may depend on the quantity of waste generated in $i$. For example, if there are scale economies in treating waste for disposal, states that generate more waste may be more likely to contain an appropriate disposal facility and therefore less likely to export that waste. Consequently, this paper focuses on variants of equation (11).

Regressors in the models that follow are suggested by the conceptual framework in section II. These include the median income, population, area, and population density of both the origin and destination states, and the log of hazardous waste generated by the origin states, $\ln \left(g_{i t}\right)$. Other regressors include origin and destination states' hazardous waste capacity, and the percentages of their populations over age 65 and with college degrees. The distance between the two states is calculated as the straight-line distance between each state's population-weighted center. ${ }^{12}$ In addition I have included year dummies, region dummies, and an indicator for the observations in which the waste is shipped within the same state.

Table 3 presents estimates of the transport equation (11) in various forms. The dependent variable is the log of TRI off-site disposal shipments among states. The 5 years of data for the 48 continental states generate 11520 observations $\left(5 \times 48^{2}\right)$. Of course, many of these annual state-

\footnotetext{
${ }^{12}$ The geographic coordinates of the states' population centers are from the Census Bureau. Their distances are approximated as a straight line along a great-circle route.
} 
pairs had no TRI waste shipped. Table 3 presents the analyses using all 11520 observations, with the dependent variable being the log of interstate shipments plus one pound. Later robustness checks use only the non-zero observations.

\section{Pooled estimations}

As a benchmark, column (1) of Table 3 contains results for the pooled data. The quantity of interstate shipments declines with the distance between states, and the squared distance term indicates that the effect diminishes slightly as distance increases. ${ }^{13}$ Waste appears more likely to be shipped from states that have large, dense, and old populations, large areas, and less hazardous waste disposal capacity. The coefficient on $\ln$ (waste generated) is positive but considerably less than 1 , indicating that waste is proportionately less likely to be shipped from states generating large volumes of waste, all else equal. This result makes sense if, for example, there are returns to scale in waste disposal and states with large generators are more likely to have in-state disposal facilities. With respect to the destination, waste appears more likely to be shipped to states that have relatively poorer, more densely populated, younger and less educated populations, and to states with more hazardous waste disposal capacity. The year indicator coefficients describe a steady decline in off-site waste disposal over time.

The most obviously improbable result in column (1) of Table 3 is the significant positive coefficient on the tax variable, suggesting that waste is more likely to be shipped to states with high disposal taxes. A likely explanation is that states that for unobserved reasons import relatively more waste respond by imposing higher taxes. In econometric terms, the error term in

\footnotetext{
${ }^{13} \mathrm{~A}$ more complicated spline yields essentially the same pattern.
} 
equation (11), $\varepsilon_{i j t}$, is correlated with the tax variable, $\tau_{i j t}$, either because the tax rates are endogenous or because some omitted characteristics of states are correlated with both tax rates and hazardous waste imports. Table 1 shows that states with hazardous waste taxes import many times as much waste as states without taxes, and this cross-state difference is being picked up by the pooled regressions in column (1). The positive coefficient is likely the result of the fact that the effect of hazardous waste imports on taxes dominates the effect of taxes on imports.

Suppose, for example, that the true version of equation (11) is

$$
\ln \left(W_{i j t}\right)=X_{i j t}^{\prime} \beta+\gamma \ln \left(g_{i t}\right)+\delta t_{i j t}+\theta \tilde{A}_{j}+\mu_{i j t}
$$

where $\tilde{A_{j}}$ is the unobserved suitability of state $j$ to hazardous waste, and $\varepsilon_{i j t}=\theta \tilde{A}_{j}+\mu_{i j t}$. This $\tilde{A}_{j}$ might include characteristics such as geological suitability to hazardous waste disposal facilities or the unobserved pre-tax price of hazardous waste disposal. Suppose further that taxes in each destination state are a function of the state's characteristics and lagged imports,

$$
\tau_{i j t}=\mathrm{F}\left(Z_{j t}, \sum_{i=1}^{M} W_{i j, t-1}\right)
$$

where $Z_{j t}$ are exogenous observable characteristics of state $j$ at time $t$, and $W_{i j, t-l}$ are last year's imports to state $j .{ }^{14}$ Because lagged imports will also be a function of $\tilde{A_{j}}$, taxes and omitted suitability are correlated $\left(\operatorname{cov}\left(\tilde{A}_{j}, \tau_{i j}\right)>0\right)$. Because $\tilde{A}_{j}$ is omitted from equation $(11)$ and its estimations in column (1) of Table 3 , the coefficient on $\tau_{i j t}$ is biased. The result here illustrates Besley and Case's (1994) warning that public economists need to examine the source of policies,

${ }^{14}$ Note that equation (13) assumes no direct simultaneity. In other words, current imports $W_{j t}{ }^{F}$ cannot directly affect current taxes $\tau_{i j r}$. Because the tax laws typically take some time to pass and to become effective, this assumption is reasonable. 
along with their incidence. In this case the bias appears to be strong enough to change the sign of the coefficient.

To account for the correlation between $\tau_{i j t}$ and $\varepsilon_{i j,}$, I take four separate approaches. The first is a "natural experiment" based on the idea that for states with retaliatory taxes, some shipments are subject to a tax that may be considered exogenous. The second approach uses the panel nature of the TRI data and a fixed-effects model with destination-state dummy variables to try to measure the unobserved $\tilde{A_{j}}$. The third approach is to estimate the exogenous part of equation (13) and to use the predicted values of $\tau_{i j t}$ as an instrument for the actual tax rates. The fourth approach extrapolates from the coefficient on the distance among states.

\section{A "Natural Experiment"}

From 1989 to 1993 , six states assessed hazardous waste disposal taxes that were the larger of some statutory value and the tax rate charged by the origin state. ${ }^{15}$ In cases where the retaliatory tax rule was binding, the tax on the shipment will not have been a function of the destination-state characteristics, observed or unobserved, equation (13) will not hold, and the tax rate in equation (11) can be considered exogenous. Consider the example depicted in Figure 1. Three states ( $\boldsymbol{a}, \boldsymbol{b}$, and $\boldsymbol{c}$ ) each ship waste to state $\boldsymbol{j}$, and each is identical in every respect but taxes. State $\boldsymbol{a}$ charges no hazardous waste disposal tax, state $\boldsymbol{b}$ charges $\$ 20$ per ton, and state $\boldsymbol{c}$ charges $\$ 40$ per ton. State $j$ charges a retaliatory tax that is the higher of $\$ 10$ or the origin state's tax. In this example, $\tau_{a j}=\$ 10$ and is endogenous as described above. However $\tau_{b j}=\$ 20$ and $\tau_{c j}=\$ 40$, and both are exogenous. The taxes charged on shipments from $\boldsymbol{b}$ to $\boldsymbol{j}$ and from $c$ to $\boldsymbol{j}$ are

\footnotetext{
${ }^{15}$ These states are IN, LA, MS, OH, OK, and SC.
} 
independent of past shipments to $j$. Furthermore, because $\tau_{b j}<\tau_{c j}$ we can expect that $W_{b j}>\mathrm{W}_{c j}$. To take advantage of this feature of the tax laws, I examine the subset of interstate transfers in which these retaliatory taxes bind and in which the resulting tax rates differ only because of origin-state characteristics--analogous to examining only $W_{b j}$ and $W_{c j}$ in Figure 1.

Column (2) of Table 3 presents estimates of equation (11) in which the sample is restricted to those state pairs for which retaliatory taxes bind. There were 294 such observations for the five years (1989-93) for which TRI data are available. For this subset of the data the tax coefficient is negative, although it is not statistically significant at conventional levels (perhaps due to the smaller sample). Nevertheless, the result differs sharply from the significant positive tax coefficient in column (1) that includes all of the state pairs. Because the subset of states used in column (2) is small and may not be representative, and because the decision to enact a retaliatory tax may itself depend on unobserved characteristics, in other approaches I account directly for the correlation between the error term in equation (11) and taxes.

Recall that the error term in equation (11) is assumed to have two components: the unobserved suitability of state $j$ for waste disposal, $\theta \tilde{A}_{j}$, and a well behaved error term, $\mu_{i j t}$. Their sum is correlated with $\tau_{i j t}$ because state $j$ 's tax rates are a function of lagged imports, which are also a function of state $j$ 's unobserved suitability. This suggests two alternate approaches to dealing with the correlation between $\varepsilon_{i j t}$ and $\tau_{i j t}$ : measuring $\tilde{A}_{j}$ directly so as to remove it from the error term, or instrumenting for $\tau_{i j r}$. The next two subsections describe each of these approaches and their results. 


\section{Fixed effects}

The tax coefficient in column (1) of Table 3 is likely to be biased because an omitted "suitability" variable will be positively correlated with imports of waste and disposal taxes, as states that experience large imports respond by levying high taxes. To account for omitted suitability, I use the panel of TRI data to estimate fixed-effects models, assuming that suitability is constant over the period examined. I estimate

$$
\ln \left(W_{i j t}\right)=\alpha_{j}^{*}+X_{i j t}^{\prime} \beta+\gamma \ln \left(g_{i t}\right)+\delta \tau_{i j t}+\mu_{i j t}
$$

where $\alpha_{j}^{*}$ is a vector of coefficients on 48 destination-state-specific dummy variables.

Column (3) of Table 3 presents estimates of (14). Except for the tax variable, the pattern of coefficient magnitudes and statistical significance here is similar to those in the pooled model in column (1). Compared with the uncorrected results in column (1), however, the tax variable in the fixed-effects model is negative and statistically significant. This suggests that there are important differences among states that make taxes appear to be positively correlated with imports in aggregate or cross-section analyses. When these differences are controlled for, even with simple dummy variables, the tax coefficient has the more intuitive negative sign. ${ }^{16}$

${ }^{16}$ Alternative fixed-effects specifications have also been explored, but are not reported here. For example, when origin-state dummy variables are included instead of destination-state dummies, they are statistically insignificant and the tax coefficients are nearly identical to those using the pooled model in column (1). This is to be expected, because unobserved origin-state characteristics are unlikely to be correlated with the destination state's tax rate. Also, when statepair-specific dummy variables are included (2304 of them), the tax coefficients are negative and statistically significant, as in column (3). 


\section{$\underline{\text { A two-stage least squares estimator }}$}

A third approach to the problem posed by the endogenous tax policy is to instrument for the tax rates. Column (4) presents a two-stage least squares (2SLS) estimate of equation (11). Three instruments are included in the first-stage regression of tax rates on the exogenous variables: the logarithm of the amount of waste generated in the destination state, the percent of the gross state product attributed to the manufacturing sector, and the percent of voters voting Republican in the 1988 presidential election. These three instruments are (arguably) exogenous to waste imports and correlated with disposal taxes.

Table 4 presents an OLS regression of tax rates on destination-state characteristics, including the three instruments. States generating more waste tend to assess lower disposal taxes, and states with more manufacturing and more Republican voters enact higher taxes, though the latter coefficient is not quite statistically significant. The validity of each of these three instruments may be questioned. In particular, it may seem unusual to characterize waste generation as exogenous with respect to the disposal tax rates, but a large empirical literature finds no effect of environmental regulations in general on plant locations and employment growth (Jaffee et al., 1995), and no effect of hazardous waste disposal taxes in particular on waste generation (Sigman, 1996). ${ }^{17}$ Furthermore, many states charge higher taxes for out-of-state waste, so even if local disposal taxes do affect local waste generation, those taxes often differ from the taxes charged for waste shipments from other states. That said, tests of the

\footnotetext{
${ }^{17}$ This literature may be changing in recent years. Becker and Henderson (1997), for example, find that federally-mandated air quality regulations have had a significant deterrent effect on new plant openings and investment.
} 
overidentifying restrictions fail at low levels of significance, as does a Lagrange multiplier test of the joint hypothesis that equation? is specified correctly and that the three instruments are valid. Nevertheless, the 2SLS results are worth presenting because they broadly confirm the natural experiment and fixed-effects results.

Column (4) of Table 3 presents a 2SLS estimate of equation? in which predicted values of $\tau_{i j t}$ are used in place of their actual values. Here again, the tax coefficient has become negative, while the rest of the coefficients remain generally unchanged. While one may question any of the three econometric approaches individually, together they support one another in showing that these taxes have had significant deterrent effects on interstate waste transport.

\section{$\underline{\text { Robustness checks }}$}

The results in Table 3 use the TRI and include all of the state-pairs, including those with no waste shipments. To check the sensitivity of the results to the exclusion of the zeros, I estimated all four models from Table 3 using only those 2697 annual state-pairs for which some TRI waste was transported. The tax coefficients from these regressions are in Table 5. The first row presents the tax coefficient from the pooled regression, and it is positive and significant, as in Table 3. The second row presents the "natural experiment," this time limited to the 107 statepairs with positive waste flow and effective retaliatory taxes. As in Table 3 the tax coefficient here is negative, though not statistically significant. Row (3) presents the model with destination-state fixed effects, and it is negative and statistically significant as before.

The fourth row of Table 5 contains the tax coefficient from a Tobit version of the fixedeffects model. In other words the entire sample is used and a Tobit specification run, but with the mean of each destination state's dependent variable subtracted from each observation. Each 
observation is therefore considered censored at a different point, depending on its destination state. If fixed effects are valid and the dependent variable is censored, the results in row (4) are biased because the means for each destination state are calculated from the censored data (Heckman and Macurdy, 1980; Honoré, 1992). Nevertheless, the tax coefficient is negative and statistically significant, and of similar magnitude.

Finally, the fifth row of Table 5 presents the 2SLS specification with only the nonzero observations. As in Table 3, the tax coefficient here is negative and statistically significant, but it is somewhat larger.

To test the sensitivity of the results to the data used, column (2) of Table 5 presents the tax coefficients using the log of RCRA hazardous waste as the dependent variable and all of the same regressors as in Table 3. ${ }^{18}$ With three years of data $(1991,1993,1995)$, there are 6912 observations. The RCRA tax coefficients follow the same general pattern as the TRI tax coefficients. The pooled specification yields a positive significant coefficient, but when the endogenous taxes are controlled for using any of the other specifications, the tax coefficient becomes negative. In the RCRA data, the "natural experiment" coefficient is significant while the fixed-effects coefficient is not, though the Tobit coefficient in row (4) is large and significant. In general, the RCRA coefficients are larger than the TRI coefficients, both with and without the zero-shipment state-pairs. This is expected, because the RCRA data measure the volume of waste including waste water and soil, while the TRI measures the quantity of toxic chemicals alone. If shippers respond to higher taxes on volume by concentrating waste (including less

\footnotetext{
${ }^{18}$ The only difference is that the year indicators are for 1993 and 1995.
} 
waste water and soil), the response as measured by the TRI will be smaller than that measured by the RCRA data.

\section{Magnitudes}

In all three approaches, the tax coefficient changes from positive and significant with the pooled data to negative and usually significant in the other specifications. The magnitudes vary, but with a few exceptions they are remarkably consistent. Table 6 compares the magnitudes of the tax coefficients from the three approaches, and adds a fourth approach based on the coefficients on the distance between origin and destination states. Column (1) of Table 6 reports the tax coefficients' point estimates from Table 3, and column (2) calculates the tax elasticities assuming average tax rates are $\$ 15$ per ton. The tax elasticities are quite large, especially given that taxes are only one component of total price. Another large component, the private cost or "gate price," averages $\$ 156$ per ton in 1993 (Peretz and Solomon, 1995). Using the sum of average private costs and taxes as a base, the resulting price elasticities calculated from the tax coefficients would range from 1.7 to 2.9 . These tax and price elasticities are probably large because disposal in different states are close substitutes for each other. The third column of Table 6 presents the percent change in shipments associated with a tax increase from $\$ 18$ per ton to $\$ 26$ per ton. This is the average increase in taxes among states that do assess hazardous waste disposal fees, from 1989 to 1993 . The different approaches lead to estimates of a decline in imports ranging from 7 to 12 percent.

As a benchmark against which to compare the magnitudes of the tax coefficients, the distance coefficients are useful. The coefficient on the miles between the origin and destination states are negative and statistically significant for all four specifications in Table 3 (and for all of 
the specifications summarized in Table 5). Omitting the natural experiment, which has a small unrepresentative sample and a much larger distance coefficient, the distance coefficients are all approximately 0.009 . The average distance TRI waste is shipped for disposal, weighted by quantity of waste, is 90 miles. Therefore the estimated elasticity of waste shipments with respect to distance shipped is approximately 0.81 . If firms are indifferent between a dollar increase in transportation costs and a dollar increase in disposal taxes, we can infer the price of transporting hazardous waste per ton per mile from the ratio of the mileage coefficient to the tax coefficient. Column (4) of Table 6 presents that calculation, and the predicted transport costs range from $\$ 0.53$ per ton-mile to $\$ 1.47$. The only published estimate of hazardous waste transport costs is $\$ 0.29$ per ton-mile (ICF, 1988 , adjusted for inflation), which falls below the predictions from the tax coefficient.

Making this benchmark calculation in reverse, it is possible to estimate the tax coefficient from the knowledge that the mileage coefficient is approximately -0.009 and the cost of transport is $\$ 0.29$ per ton per mile. Row (4) of Table 6 shows that the predicted tax coefficient would be -0.031 . At an average 1993 tax rate of about $\$ 15$, this translates to an elasticity of 0.47 , and an increase from $\$ 18$ to $\$ 26$ would be associated with a 21 percent drop in shipments to states raising their taxes. These estimates are high relative to those provided by the tax coefficients directly. One reason for the larger measured elasticity of distance costs than tax costs might be that distances are permanent, while there may be a short-term or temporary element to the estimated tax elasticities. Waste shippers may take time to adjust to disposal price and tax changes, perhaps because they sign long-term contracts, whereas responses to distances among states are certainly completely reflected in current transport patterns. Finally, recall that 
the proponents of Alabama's $\$ 72$ per-ton import tax argued that it halved the amount of waste being disposed in Alabama. That claim seems easily plausible given the empirical findings summarized in Table 6.

\section{Conclusions.}

This paper has shown that interstate competition in hazardous waste disposal taxes has significantly affected patterns of hazardous waste disposal in the U.S. in recent years, by decreasing shipments of waste to states enacting high disposal taxes. In addition, Tables 2 and 4 show that disposal taxes are largest and have increased most in states that have large capacity or import large quantities of waste. Together, these two conclusions imply that state hazardous waste disposal taxes have increased the decentralization of hazardous waste disposal relative to the hypothetical case in which hazardous waste disposal taxes are equal across states. If there are economies of scale or safety in centralized hazardous waste disposal, then the results here cast doubt on the wisdom of decentralizing environmental policy itself. However the welfare implications are ambiguous. On one hand, transport of hazardous waste between states presents its own set of negative externalities, and a policy encouraging local disposal alleviates those problems. On the other hand, decentralized (local) disposal could have adverse economic and environmental consequences. Without knowing the external costs of hazardous waste transport relative to the benefits of centralized disposal, it is impossible to pass judgement on the welfare consequences of hazardous waste tax competition. Nevertheless, by estimating the effect of that competition on disposal patterns, this research has shown that decentralized hazardous waste 
disposal appears to be one important consequence of shifting environmental regulatory responsibility to the states. 


\section{REFERENCES}

Becker, Randy and Vernon Henderson. "Effects of Air Quality Regulation on Decisions of Firms in Polluting Industries," NBER working paper \#6160, September, 1997.

Besley, Timothy and Anne Case. "Unnatural Experiments: Estimating the Incidence of Endogenous Policies," NBER working paper \#4956, December, 1994.

Commerce Clearing House. State Tax Guide 2nd edition. Chicago, IL: Commerce Clearing House, 1996.

Commerce Clearing House. Tax Day. Chicago, IL: Commerce Clearing House, various issues.

Council on Environmental Quality (CEQ). Environmental Quality. Washington, DC: CEQ, 1992.

Cropper, Maureen L. and Wallace E. Oates. "Environmental Economics: A Survey." Journal of Economic Literature, 1992, 30, pp. 675-740.

DaVanzo, Julie. "Microeconomic Approaches to Studying Migration Decisions," in Gordon F. De Jong and Robert W. Gardner, eds., Migration Decision Making: Multidisciplinary Approaches to Microlevel Studies in Developed and Developing Countries. New York: Pergamon Press, 1981.

Environmental Protection Agency (EPA), Office of Policy Analysis. 1986-87 Survey of Selected Firms in the Commercial Hazardous Waste Management Industry. Washington, DC: EPA, March 31, 1988.

Environmental Protection Agency (EPA), Office of Solid Waste and Emergency Response. National Biennial RCRA Hazardous Waste Report (Based on 1989 Data), EPA530-R992-027. Washington, DC: EPA, February, 1993.

Environmental Protection Agency (EPA) Office of Solid Waste and Emergency Response. National Capacity Assessment Report: Capacity Planning Pursuant to CERCLA Section 104(c)(9): DRAFT, EPA530-R-94-040. Washington, DC: EPA, October, 1994.

Heckman, James J. and Thomas E. Macurdy. "A Life Cycle Model of Female Labour Supply." Review of Economics and Statistics, 1980, 47, pp. 47-74.

Honoré, Bo. "Trimmed LAD and Least Squares Estimation of Truncated and Censored Regression Models With Fixed Effects." Econometrica, 1992, 60(3), pp. 533-565. 
Jaffee, Adam B., Steven R. Peterson, Paul R. Portney, and Robert Stavins. "Environmental Regulation and the Competitiveness of U.S. Manufacturing." The Journal of Economic Literature, 1995, 33(1), pp. 132-163.

Markusen, James, Edward Morey and Nancy Olewiler. "Competition in Regional Environmental Policies When Plant Locations Are Endogenous." Journal of Public Economics, 1995, 56, pp. 55-77.

Mitchell, R.C. and Carson, R.T. "Property Rights, Protest, and the Siting of Hazardous Waste Facilities," American Economic Review, 1986, 76, pp. 285-90.

Oates, Wallace E. and Robert M. Schwab. "Economic Competition Among Jurisdictions: Efficiency Enhancing or Distortion Inducing?" Journal of Public Economics, 1988, 35 , pp. 333-354.

Peretz, Jean H. and Jeffrey Solomon. "Hazwaste Landfill Costs on Decline, Survey Says." Environmental Solutions, April, 1995.

Peltzman, Sam, and T. Nicholaus Tideman. "Local Versus National Pollution Control: Note," American Economic Review, December, 1972.

Roper Organization, Inc. "Environmental Protection in the 1990s: What the Public Wants" presentation to the U.S. EPA, June 1991 cited in Walter A. Rosenbaum, Environmental Politics and Policy. Washington, DC: Congressional Quarterly Press, 1995.

Stein, Jerome L. "The 1971 Report of the President's Council of Economic Advisers: MicroEconomic Aspects of Public Policy." American Economic Review, September, 1971.

Schultz, Paul T. "Lifetime Migration within Educational Strata in Venezuela: Estimates of a Logistic Model." Economic Development and Cultural Change, 1982, 30, pp. 559-93.

Sigman, Hilary. "The Effects of Hazardous Waste Taxes on Waste Generation and Disposal." Journal of Environmental Economics and Management, 1996, 30, pp. 199-217.

Smith, V.K. and Desvousges, W.H. "The Value of Avoiding a LULU: Hazardous Waste Disposal Sites." Review of Economics and Statistics, 1986, 68, pp. 293-99.

Walters, Jonathan. "The Poisonous War Over Hazardous Waste," Governing, November, 1991. 
Figure 1. Retaliatory taxes.

a (\$0/ton)

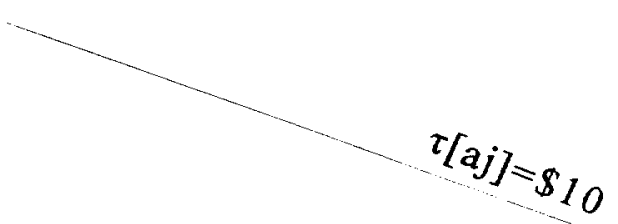

b (\$20/ton)

$$
\tau[\mathrm{bj}]=\$ 20 \rightarrow \mathrm{j}(\max [\$ 10, \text { origin }])
$$

c $(\$ 40 /$ ton $)$ 
Table 1. Average State Characteristics For States With and Without Hazardous Waste Disposal Taxes, 1991.

States Without
HW Disposal Taxes

(1)

\begin{tabular}{lcr} 
& $(1)$ & $(2)$ \\
\hline Number of states & 20 & 28 \\
$\begin{array}{l}\text { Median household income } \\
\text { (1989) }\end{array}$ & $\$ 28818$ & $\$ 28519$ \\
Population & $(1261)$ & $(930)$ \\
1990 (thousands) & 3585 & $6241^{\star}$ \\
Land area & $(705)$ & $(1235)$ \\
(square miles) & 53582 & $67423^{\star}$ \\
Population density & $(8673)$ & $(9772)$ \\
(persons/sq. mile) & 187 & $157^{\star}$ \\
Percent over age 65 & $(67)$ & $(36)$ \\
& 13.22 & $12.64^{*}$ \\
Percent with college degree & $(0.48)$ & $(0.29)$ \\
& 13.27 & $12.57^{\star}$ \\
Waste generated 1991 & $(0.54)$ & $(0.44)$ \\
(thousand tons, RCRA) & 3136 & $8561^{*}$ \\
Waste capacity 1989 & $(1610)$ & $(3911)$ \\
(thousand tons, RCRA) & 2252 & 2260 \\
Waste imports 1991 & $(1369)$ & $(450)$ \\
(tons, TRI) & 198 & $1023^{\star}$ \\
Waste imports 1991 & $(81)$ & $(296)$ \\
(tons, RCRA) & 1561 & $34665^{\star}$ \\
\hline
\end{tabular}

States With HW

Disposal Taxes

(2)

8519

6241

$67423^{*}$

$2.64^{*}$

$12.57^{*}$

2260

$(10039)$

Sample standard errors in parentheses.

*Difference in means statistically significant at 5 percent.

Sources: USA Counties, U.S. Census Bureau; Commerce Clearing House; calculations from Toxics Release Inventory (TRI) and Resource Conservation and Recovery Act (RCRA) form WR. 


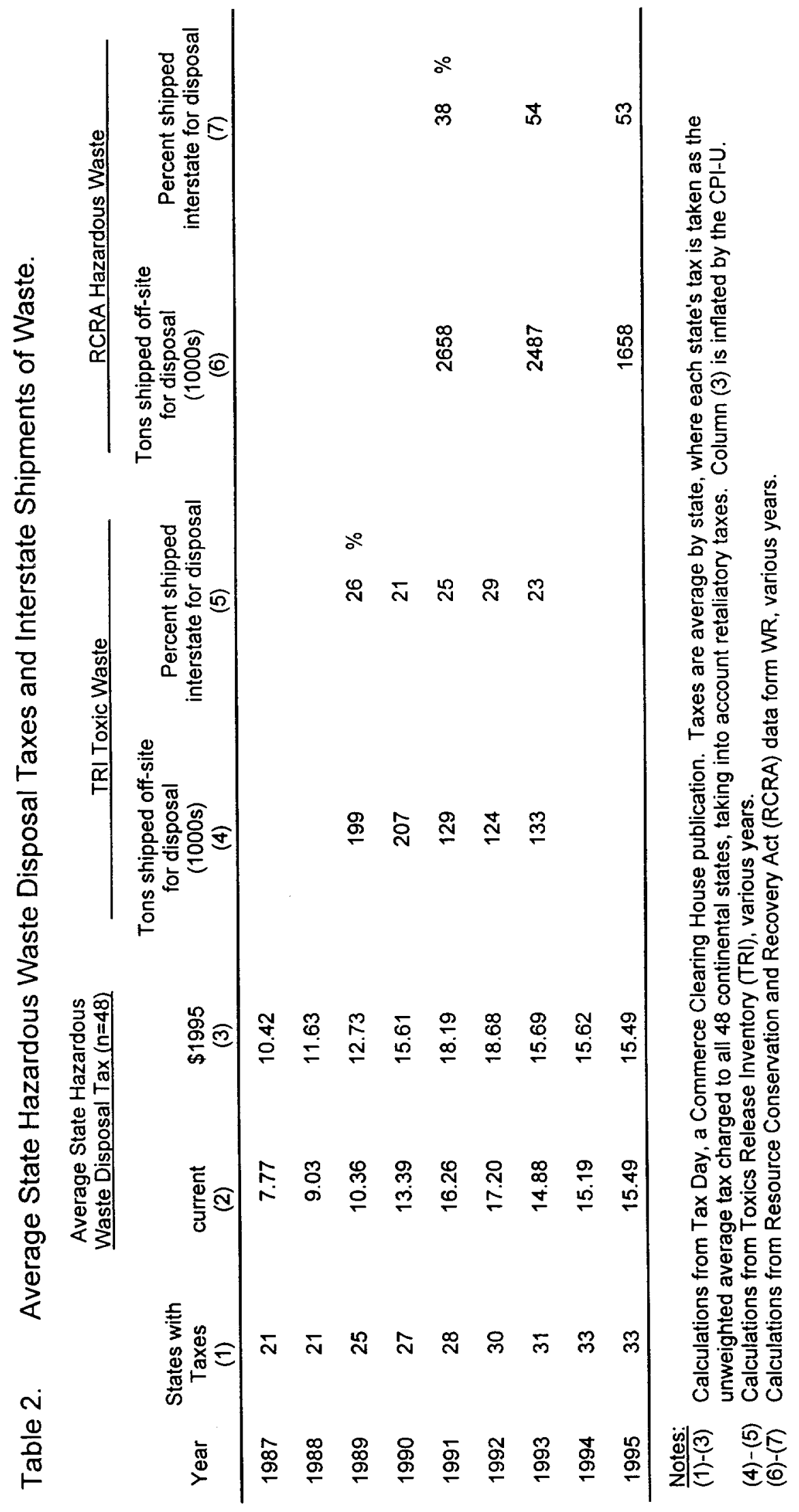


Table 3. Waste Shipments and State Characteristics: Annual TRI Data. 1989-93.

Dependent variable: $\log$ of disposal.

\begin{tabular}{|c|c|c|}
\hline Pooled & "Natural & Fixed Effects \\
\hline & $\begin{array}{c}\text { Experiment" } \\
\begin{array}{c}\text { Retaliatory } \\
\text { taxes }^{\text {a }}\end{array}\end{array}$ & $\begin{array}{l}\text { Destination- } \\
\text { state fixed } \\
\text { effects }^{b}\end{array}$ \\
\hline
\end{tabular}

Tax
Miles
$\begin{aligned} & \text { Miles squared } \\ & \text { (thousandths) }\end{aligned}$
$\begin{aligned} & \text { Origin ST median } 1989 \\ & \text { income (\$1000) }\end{aligned}$

Origin ST population (millions)

\section{Origin ST area}

(million sq. miles)

Origin ST density

(persons/sq. mile)

Origin ST percent

over age 65

Origin ST percent with college

degree

Origin ST capacity

(million tons, 1991)

Origin ST In(waste generated)

Destination ST median

income $(\$ 10001989)$

Destination ST population

(millions)
(1)

(2)

$0.0051^{*}$
$(0.0016)$

$-0.0090^{*}$

(0.0002)

$$
2.66^{\star}
$$

$(0.08)$

$-0.0119$

$(0.0120)$

$0.0557^{*}$

(0.0093)

$3.54^{*}$

(1.05)

$0.0008^{*}$

$(0.0002)$

$0.0372^{\dagger}$

(0.0203)

0.0103

(0.0184)

$-0.0142$

(0.0090)

$0.1988^{*}$

$(0.0185)$

$-0.0822^{*}$

(0.0132)

$0.0896^{*}$

(0.0082)
(3)

$-0.0098^{*}$

(0.0032)

$-0.0092^{*}$

(0.0002)

$$
2.74^{*}
$$

(0.08)

$5.40^{*}$
$(0.89)$

0.1259

(0.1475)

0.0586

$(0.0560)$

2.53

(8.34)

0.0010

(0.0032)

$-0.0698$

(0.1645)

$-0.2265$

(0.2396)

$-0.1344$

(0.1025)

0.0356

(0.1714)

0.0108

(0.1283)

$-0.0140$

(0.0114)

$0.0577^{*}$

(0.0086)

3.5291*

(0.9799)

$0.0008^{*}$

(0.0002)

$0.0363^{\star}$

(0.0183)

0.0122

(0.0177)

$-0.0135^{\dagger}$

(0.0082)

$0.1963^{*}$

(0.0178)

2SLS

Estimates

Predicted taxes
(4)

$-0.0171^{*}$

(0.0065)

$-0.0091^{*}$

(0.0002)

$2.72^{*}$

(0.09)

$-0.0149$

(0.0134)

$0.0585^{\star}$

$(0.0089)$

$3.35^{*}$

(1.06)

$0.0008^{*}$

(0.0002)

$0.0356^{\dagger}$

(0.0208)

0.0110

(0.0213)

$-0.0135$

(0.0082)

$0.1989^{*}$

(0.0210)

$-0.1172^{*}$

(0.0175)

$0.1365^{*}$

(0.0157)

(continued) 
Table 3 continued.

\begin{tabular}{|c|c|c|c|c|}
\hline $\begin{array}{l}\text { Destination ST area } \\
\text { (1000 sq. miles) }\end{array}$ & $\begin{array}{r}2.28^{\dagger} \\
(1.36)\end{array}$ & $\ddagger$ & & $\begin{array}{c}0.3457 \\
(1.2793)\end{array}$ \\
\hline $\begin{array}{l}\text { Destination ST density } \\
\text { (persons/ sq. mile) }\end{array}$ & $\begin{array}{r}0.0018^{*} \\
(0.0002)\end{array}$ & $\begin{array}{l}-0.0007 \\
(0.0057)\end{array}$ & & $\begin{array}{r}0.0016^{\star} \\
(0.0003)\end{array}$ \\
\hline $\begin{array}{l}\text { Destination ST percent } \\
\text { over age } 65\end{array}$ & $\begin{array}{r}-0.405^{\star} \\
(0.022)\end{array}$ & $\begin{array}{l}-0.3974 \\
(0.5162)\end{array}$ & & $\begin{array}{r}-0.4704^{*} \\
(0.0304)\end{array}$ \\
\hline $\begin{array}{l}\text { Destination ST percent with } \\
\text { college degree }\end{array}$ & $\begin{array}{r}-0.245^{\star} \\
(0.020)\end{array}$ & $\begin{array}{r}1.9389^{\star} \\
(0.2963)\end{array}$ & & $\begin{array}{r}-0.2565^{\star} \\
(0.0219)\end{array}$ \\
\hline $\begin{array}{l}\text { Destination ST capacity } \\
\text { (million tons, 1991) }\end{array}$ & $\begin{array}{r}0.0685^{\star} \\
(0.0081)\end{array}$ & $\begin{array}{r}0.4386^{\star} \\
(0.1176)\end{array}$ & & $\begin{array}{r}0.0707^{\star} \\
(0.0083)\end{array}$ \\
\hline Same state & $\begin{array}{l}6.08^{*} \\
(0.19)\end{array}$ & & $\begin{array}{r}5.88^{*} \\
(0.18)\end{array}$ & $\begin{array}{r}5.95^{\star} \\
(0.24)\end{array}$ \\
\hline Year $=1990$ & $\begin{array}{c}0.014 \\
(0.096)\end{array}$ & $\begin{array}{c}0.200 \\
(0.795)\end{array}$ & $\begin{array}{c}0.059 \\
(0.088)\end{array}$ & $\begin{array}{c}0.082 \\
(0.097)\end{array}$ \\
\hline Year=1991 & $\begin{array}{r}-0.398^{\star} \\
(0.099)\end{array}$ & $\begin{array}{c}0.299 \\
(0.792)\end{array}$ & $\begin{array}{r}-0.306^{\star} \\
(0.091)\end{array}$ & $\begin{array}{r}-0.267^{\star} \\
(0.106)\end{array}$ \\
\hline Year=1992 & $\begin{array}{r}-0.474^{*} \\
(0.099)\end{array}$ & $\begin{array}{c}0.917 \\
(0.837)\end{array}$ & $\begin{array}{r}-0.368^{*} \\
(0.093)\end{array}$ & $\begin{array}{r}-0.322^{\star} \\
(0.109)\end{array}$ \\
\hline Year=1993 & $\begin{array}{r}-0.444^{\star} \\
(0.100)\end{array}$ & $\begin{array}{c}-0.022 \\
(0.839)\end{array}$ & $\begin{array}{r}-0.373^{\star} \\
(0.094)\end{array}$ & $\begin{array}{r}-0.344^{*} \\
(0.104)\end{array}$ \\
\hline West & $\begin{array}{c}-0.631^{\star} \\
(0.106)\end{array}$ & & & $\begin{array}{r}-0.548^{*} \\
(0.114)\end{array}$ \\
\hline Northeast & $\begin{array}{c}-0.113 \\
(0.116)\end{array}$ & & & $\begin{array}{c}0.172 \\
(0.145)\end{array}$ \\
\hline South & $\begin{array}{c}0.063 \\
(0.098)\end{array}$ & & & $\begin{array}{c}-0.007 \\
(0.094)\end{array}$ \\
\hline Constant & $\begin{array}{r}13.35^{\star} \\
(0.79)\end{array}$ & $\begin{array}{c}-4.60 \\
(8.85)\end{array}$ & & $\begin{array}{c}15.52^{*} \\
(1.05)\end{array}$ \\
\hline $\begin{array}{l}\text { Observations } \\
\text { Zeros } \\
\mathrm{R}^{2}\end{array}$ & $\begin{array}{r}11520 \\
8823 \\
0.45\end{array}$ & $\begin{array}{r}294 \\
187 \\
0.54\end{array}$ & $\begin{array}{r}11520 \\
8823 \\
0.53\end{array}$ & $\begin{array}{r}11520 \\
8823 \\
0.44\end{array}$ \\
\hline
\end{tabular}

Heteroskedastic-consistent standard errors in parentheses.

+ Statistically significant at 10 percent.

* Statistically significant at 5 percent.

- The relevant destination states in column (2) are IN, LA, MS, OH, OK, SC.

${ }^{\circ}$ Column (3) includes 48 destination-state fixed effects.

$\ddagger$ Dropped due to collinearity. 
Table 4. Hazardous Waste Taxes As a Function of State Characteristics.

Dependent variable: State-pair specific hazardous waste tax.

$\ln$ (Waste generated)

Manufacturing \% earnings 1990

Percent voting Republican in 1988

presidential election

Median household

$-1.86^{*}$

Income 1989 (\$1000)

$(0.07)$

Population 1990

Area

(million sq. miles)

Population density

Hazardous waste capacity

$0.72^{\star}$

(million tons, 1991)

Percent over age 65

Percent with college degree

Same state

Year $=1990$

$4.66^{\star}$

$(0.50)$

Year=1991

$7.57^{\star}$

(0.59)

Year $=1992$

Year=1993

West

Northeast

South

Constant 


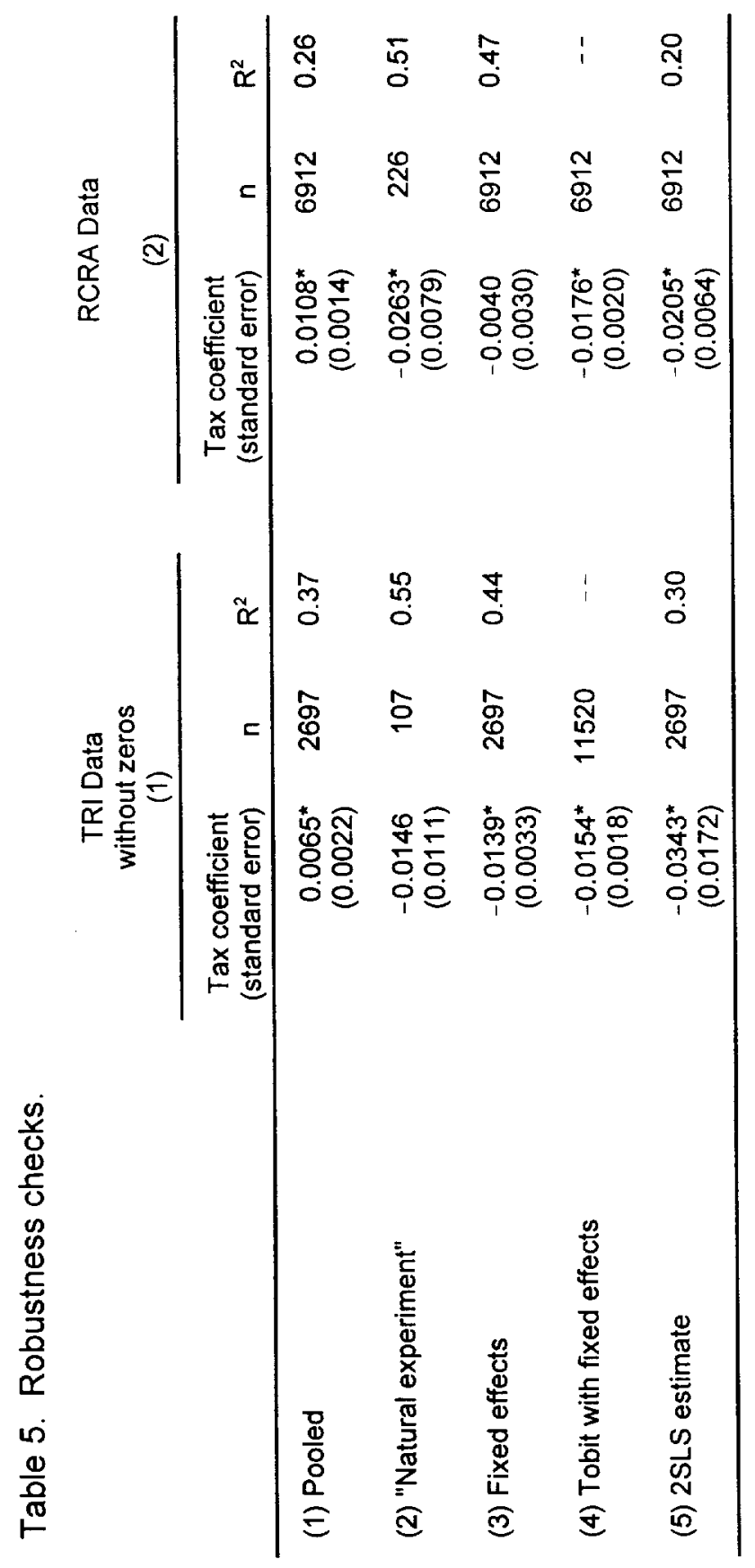




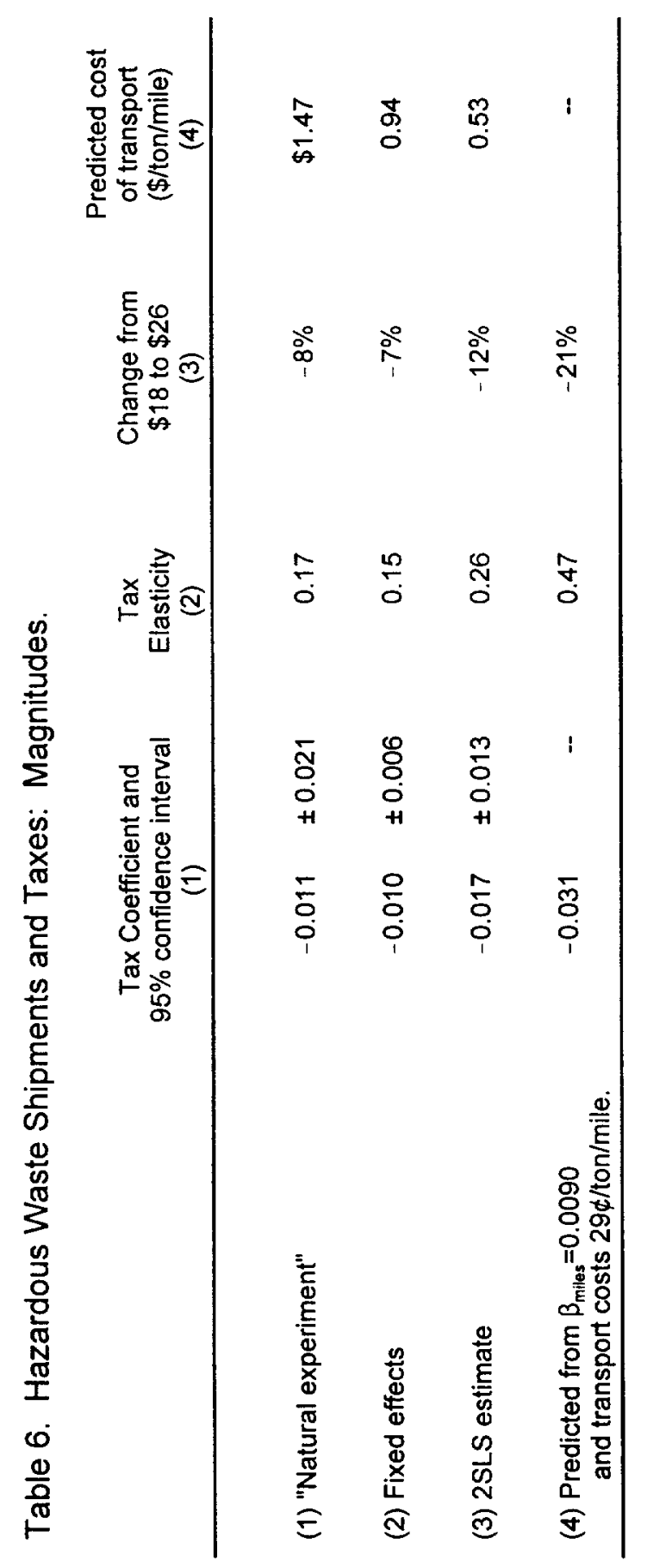

